\title{
Karakterisasi Morfologi dan Pengaruh Perlakuan Pemupukan dan Pemberian Silika (Si) pada Genotipe Hibrida Anggrek Cattleya
}

\section{Morphological Characterization and Effects of Treatments Fertilization and Gift Silica (Si) on Genotype Hybrid Cattleya Orchids}

\section{Adimas Krishardianto dan Dewi Sukma*}

\author{
Departemen Agronomi dan Hortikultura, Fakultas Pertanian, Institut Pertanian Bogor, Jalan Meranti, \\ Kampus IPB Darmaga, Bogor 16680, Indonesia \\ Telp.\&Faks.62-251-8629353 e-mail agronipb@indo.net.id \\ *Penulis untuk korespondensi: dsukma70@yahoo.com
}

Disetujui 17 Mei 2017/Published online 22 Mei 2017

\begin{abstract}
Cattleya is an orchid which has large flowers and called as queen of orchid. It has the beauty of flower color variation. Use of fertilizer in equilibrium would increase crop production. Silica could strengthens the plant tissues that support plant resistant to disease and pests. The research aims was to determine the effect of fertilizer and silica (Si) on growth and developmet of some Cattleya orchid hybrids. The experiment was placed at Orchid House Department of Agronomy and Horticulture, IPB and carried out from April to July 2015. This research used Completely Randomized Design by a single factor namely fertilization treatment. Four treatments used were complete liquid organic fertilizer $2 \mathrm{ml} \mathrm{L}^{-1}$, NPK 32:10:10 $2 \mathrm{~g} \mathrm{~L}^{-1}$, complete liquid organic fertilizer $2 \mathrm{ml} \mathrm{L}^{-1}+$ silica $2.5 \mathrm{ml} \mathrm{L}^{-1}$, and NPK 32:10:10 $2 \mathrm{~g} \mathrm{~L}^{-1}+$ silica 2.5 $m l L^{-1}$. Each treatment consisted of three replications with 3 plants. The replication characterization results indicate there is no diversity cross section of leaves and flowering position, tip shape, texture, shape and texture of the surface edges of the leaves, flowering types, resupination, jewelry, as well as the shape of flowers. Fertilizer that gives best results for the three genotypes is a complete liquid organic fertilizer added silica (Si) on five parameters, namely number, length, width and thickness of leaves, as well as emerging new tillers.
\end{abstract}

Keywords: complete liquid organic fertilizer, growmore, silica (Si), hybrid, Cattleya

\begin{abstract}
ABSTRAK
Cattleya merupakan anggrek yang memiliki bunga dengan ukuran besar dan disebut queen of orchid karena memiliki keindahan dari variasi warna pada bunganya. Pemupukan berperan penting dalam pertumbuhan dan perkembangan tanaman. Silika berperan dalam memperkuat jaringan tanaman sehingga lebih tahan serangan penyakit dan hama. Penelitian ini bertujuan untuk mengetahui pengaruh pemupukan dan pemberian silika (Si) terhadap pertumbuhan beberapa hibrida anggrek Cattleya. Penelitian dilakukan di rumah Anggrek Departemen Agronomi dan Hortikultura, IPB pada bulan April hingga Juli 2015. Percobaan dilakukan menggunakan Rancangan Kelompok Lengkap Teracak (RKLT) dengan faktor tunggal yaitu perlakuan pemupukan. Terdapat empat perlakuan yaitu pupuk organik cair lengkap $2 \mathrm{ml} \mathrm{L}^{-1}$, NPK 32:10:10 $2 \mathrm{~g} \mathrm{~L}^{-1}$, pupuk organik cair lengkap $2 \mathrm{ml} \mathrm{L}^{-1}+$ silika $2.5 \mathrm{ml} \mathrm{L}^{-1}$, dan NPK 32:10:10 $2 \mathrm{~g} \mathrm{~L}^{-1}+$ silika $2.5 \mathrm{ml} \mathrm{L}^{-1}$. Perlakuan terdiri dari tiga kali ulangan, setiap ulangan terdiri dari 3 tanaman. Hasil karakterisasi menunjukan tidak terdapat keragamaan pada penampang melintang daun serta posisi pembungaan, bentuk ujung, susunan, bentuk tepi dan tekstur permukaan daun, tipe pembungaan, resupinasi, perhiasan, serta bentuk bunga. Pupuk yang memberikan hasil paling baik untuk ketiga genotipe adalah pupuk organik cair lengkap ditambahkan silika (Si) pada 5 parameter pengamatan yaitu pertambahan jumlah, panjang, lebar dan tebal daun, serta muncul anakan baru.
\end{abstract}

Kata kunci: Cattleya, grow more, hibrida, pupuk organik cair lengkap, silika (Si) 


\section{PENDAHULUAN}

Anggrek (Orchidaceae) merupakan salah satu jenis tanaman hias berbunga yang cukup digemari di Indonesia dan termasuk family Orchidaceae yang memiliki sekitar 800 genus dan 25000 spesies. Tanaman anggrek termasuk tanaman monokotil, tahunan dan berbentuk herba. Daya tarik pada tanaman ini terletak pada keindahan bentuk bunga dan warna bunga yang beraneka ragam sehingga para pecinta anggrek tidak merasa bosan menikmati keindahannya (Mattjik 2010). Produksi anggrek tahun 2011 mencapai 15490256 tangkai, tahun 2012 mencapai sebanyak 20727891 tangkai dan pada tahun 2013 sebanyak 20277672 tangkai (BPS 2014). Ekspor anggrek pada tahun 2012 ke beberapa negara seperti Taiwan, Singapura, Malaysia, Australia, Korea dan Jepang adalah 69 $353 \mathrm{~kg}$, menurun pada tahun 2013 sebanyak 58 $656 \mathrm{~kg}$ (BPS 2014). Puspitasari (2006) menyatakan besarnya perolehan yang fluktuatif ini menunjukkan bahwa perlu adanya suatu peningkatan kualitas dan kuantitas anggrek agar dapat meningkatkan nilai ekonomi tanaman anggrek.

Sebagian besar anggrek terdapat dan berasal dari negara yang memiliki banyak bukit dan pegunungan, meskipun tanaman ini mampu tumbuh di daerah intermediet (Sander 1979). Salah satu jenis anggrek yang banyak digemari adalah genus Cattleya. Tanaman ini termasuk dalam anggrek simpodial yaitu anggrek yang tidak memiliki batang utama, bunga ke luar dari ujung batang dan berbunga kembali dari anak tanaman yang tumbuh. Iswanto (2010) menyatakan bahwa Cattleya memiliki ciri khas yaitu bentuk bunga yang besar dengan warna yang bervariasi dan ketahanan terhadap suhu dengan tingkat sedang. Santi (2005) menyatakan bahwa tanaman anggrek Cattleya tumbuh dengan sehat dan kuat apabila kebutuhan unsur hara makro dan mikro terpenuhi, sedangkan kandungan unsur hara dalam media pakis jumlahnya kurang memenuhi sehingga mutlak diperlukan untuk pemupukan.

Anggrek membutuhkan beberapa unsur hara untuk pertumbuhannya. Brown dan Caligari (2006) menyatakan bahwa adaptasi tanaman dapat berupa pengaturan produksi makanan, masa reproduksi dan penyebaran keturunan yang disesuaikan dengan keadaan lingkungan. Defisiensi hara dapat terjadi jika konsentrasi unsur hara berada dibawah konsentrasi yang dibutuhkan agar anggrek tumbuh optimal (Hew dan Young 1997). Dua cara untuk mensuplai hara ke dalam tanaman yaitu pemupukan melalui akar dan daun (Soepardi 1983). Pemupukan akan lebih efektif apabila diberikan pada permukaan daun bagian bawah (Santi et al. 1996). Daun mampu menyerap pupuk sekitar 90\% sedangkan akar hanya mampu menyerap 10\% (Iswanto 2001). Tisdale et al (1995) menyatakan bahwa pemupukan melalui daun penyerapan hara oleh tanaman dapat dilakukan lebih cepat dibandingkan melalui akar karena dapat menembus kutikula dan stomata sehingga langsung masuk ke dalam sel jaringan. Umumnya pemupukan melalui daun menggunakan alat semprot namun ada juga yang dilakukan dengan cara langsung menyiram daun tanaman (Wahyono et al. 2009).

Silika (Si) merupakan unsur hara yang memberi banyak manfaat bagi tanaman, khususnya tanaman akumulator $\mathrm{Si}$ seperti padi dan tebu. Silika $(\mathrm{Si})$ merupakan salah satu unsur kimia kedua terbanyak di kerak bumi (lithosphere) yaitu 27.6\% dan diserap oleh hampir semua tanaman dalam bentuk asam monosilikat (monosilicic acid) atau $\mathrm{Si}(\mathrm{OH})_{4}$ (Tisdale et al. 1995). Silika merupakan unsur yang paling banyak terdapat di dalam tanah dalam bentuk mineral alumunium silikat. Mineral tersebut dalam bentuk padat yang melalui proses pelapukan diurai menjadi sumber unsur yang tersedia bagi tanaman, oleh karena itu tanaman yang tumbuh di atas tanah, akan mengandung unsur $\mathrm{Si}$ yang terdapat dalam hampir semua jaringan dengan kadar antara 0.1-10\% (Esptein 1999).

Peran Si salah satunya adalah sebagai proteksi tanaman terhadap keadaan yang kurang menguntungkan. Penggunaan $\mathrm{Si}$ sangat mempengaruhi pertumbuhan tanaman, berdampak pada penguatan batang tanaman, perlindungan tanaman dari hama, penguatan akar dan lain-lain (Ma dan Takahashi 2002). Peran hara Si bagi tanaman dapat menstimulasi fotosintesis dan translokasi karbon dioksida $\left(\mathrm{CO}_{2}\right)$. Unsur Si juga dapat mengurangi cekaman abiotik, seperti suhu, radiasi cahaya, angin, air, dan kekeringan, serta meningkatkan resistensi tanaman terhadap cekaman biotik, seperti serangan penyakit dan hama. Silika memperkuat jaringan tanaman sehingga lebih tahan terhadap serangan penyakit dan hama. Fungsi ini mirip dengan peran $\mathrm{K}$ bagi tanaman (PIOC 2014).

Tujuan penelitian ini adalah mengetahui pengaruh pemupukan dan silika ( $\mathrm{Si}$ ) terhadap pertumbuhan anggrek Cattleya sp. Hipotesis yang akan diuji dalam penelitian ini adalah genotipe yang berbeda memiliki laju pertumbuhan yang berbeda dan kombinasi pupuk dengan silika $(\mathrm{Si})$ dapat meningkatkan pertumbuhan tanaman pada semua genotipe yang di uji. 


\section{BAHAN DAN METODE}

Penelitian dilaksanakan pada bulan April sampai Juli 2015. Penelitian bertempat di "Rumah Angle" rumah anggrek Departemen Agronomi dan Hortikultura, IPB. Penelitian dimulai dengan kegiatan repotting dan membagi tanaman menjadi masing - masing pot terdiri dari 2 bulb bahan tanaman yang sudah tersedia sebelumnya, selanjutnya masing-masing unit percobaan dilakukan pemeliharaan yaitu berupa penyiraman yang dilakukan 6 hari sekali dan penyemprotan vitamin B1 dilakukan setiap 6 hari sekali, pemeliharaan rutin meliputi pengendalian penyakit dengan fungisida dan bakterisida.

Bahan tanaman yang digunakan dalam penelitian ini adalah 3 genotipe anggrek Cattleya hibrida, yaitu : Cattleya Mantini (C. Dowiana x $C$. Bowringiana), Cattleya Chun Yeah (Tassi Barbero x Kuan Miao Chen), Cattleya Warneri Purple Tounge (C. Warnerif. Semi-Alba Orlata $x$ C. Warneri Coerulea Suzuki). Media tanam berupa pakis cacah, arang dan sphagnum moss. Fungisida (Dythane-45 atau Antrachol), bakterisida (Agrept), silika (Si) dengan merek dagang Novelgro Silika, air, pupuk organik cair lengkap dengan merek dagang Bio Sugih Tani, pupuk anorganik untuk daun dan bunga dengan merek dagang Grow More Research Farms (3210-10), dan Grow More (10-55-10) serta Vitamin B1 dengan merek Liquinox Start.

Karakterisasi pada karakter morfologi dan pertumbuhan 3 genotipe hibrida anggrek Cattleya ini dilaksanakan sesuai dengan panduan karakterisasi anggrek Balai Penelitian Tanaman Hias (2007). Parameter yang digunakan dalam pengamatan adalah kuantitatif dan kualitatif.

Percobaan disusun menggunakan Rancangan Kelompok Lengkap Teracak (RKLT) dengan 1 faktor perlakuan yaitu konsentrasi pupuk dimana terdapat 4 taraf pemupukan. Percobaan dilakukan secara terpisah pada 3 populasi tanaman hibrida. Perlakuan yang digunakan yaitu pupuk organik cair lengkap $2 \mathrm{ml}$ $\mathrm{L}^{-1}$ (P1), NPK 32:10:10 $2 \mathrm{~g} \mathrm{~L}^{-1}$ (P2), pupuk organik cair lengkap $2 \mathrm{ml} \mathrm{L}^{-1}+$ silika $2.5 \mathrm{ml} \mathrm{L}^{-1}$ (P3), dan NPK 32:10:10 $2 \mathrm{~g} \mathrm{~L}^{-1}+$ silika $2.5 \mathrm{ml} \mathrm{L}^{-1}$ (P4).

Tanaman anggrek yang digunakan terdiri atas tiga genotipe, yaitu Cattleya Mantini ( $C$. Dowiana x C. Bowringiana) (G1), Cattleya Chun Yeah (Tassi Barbero x Kuan Miao Chen) (G2), Cattleya Warneri Purple Tounge (C. Warneri $f$. Semi-Alba Orlata x C. Warneri Coerulea Suzuki) (G3). Setiap perlakuan terdiri atas tiga ulangan pada masing-masing genotipe. Tanaman berupa 2 bulb dalam satu pot. Setiap ulangan terdiri atas 3 tanaman sehingga jumlah tanaman adalah 108 tanaman.

Parameter kuantitatif yang diamati adalah pertambahan jumlah daun, pertambahan panjang daun, pertambahan lebar daun, pertambahan tebal daun, serta muncul anakan baru. Parameter kualitatif pengamatan dilakukan meliputi keragaan umum tanaman yang dibagi menjadi penampang melintang daun, dan posisi pembungaan. Pengamatan daun meliputi bentuk daun, bentuk ujung daun, susunan daun, bentuk tepi daun, tekstur permukaan daun, serta simetri daun. Pengamatan pembungaan meliputi tipe pembungaan, resupinasi (berputar hampir atau lebih dari $180^{\circ}$ ke arah porosnya), perhiasan bunga, serta bentuk bunga.

\section{HASIL DAN PEMBAHASAN}

\section{Kondisi Umum}

Bahan tanam diletakkan pada rak besi diatas kolam berisi air yang biasa dipakai untuk memelihara lele, hal ini memungkinkan untuk menjaga kelembapan dari bahan tanam. Iswanto (2010) menyatakan bahwa kelembapan yang diperlukan untuk anggrek Cattleya adalah sebesar $45-80 \%$ sehingga penyiraman dapat dilakukan ketika media tanam mulai mengering. Kelembapan dalam rumah anggrek pada bulan April sampai dengan Juli 2015 pada siang hari rata-rata sebesar $40-45 \%$ sedangkan pada malam hari rata-rata sebesar $60-70 \%$. Fluktuasi penyiraman ditambahkan ketika tanaman akan berbunga dan sudah memproduksi bunga.

Perlakuan pemupukan seluruhnya
dilakukan dengan cara disemprotkan menggunakan sprayer dan dilakukan pada pagi hari. Menurut Lingga (1992) bahwa pemupukan melalui daun dengan konsentrasi dan interval pemberian yang tepat akan lebih menguntungkan tanaman hal ini karena penyerapan hara pupuk berjalan lebih cepat, sehingga tanaman cepat menumbuhkan tunas.

Faktor yang berpengaruh dalam pertambahan tinggi tanaman adalah ketersediaan air, cahaya, temperatur, dan kelembapan udara yang optimal, apabila hal tersebut dipenuhi maka dapat memacu pertumbuhan tanaman melalui pembelahan dan pemanjangan sel (Sitompul dan Bambang 1995). Bahan tanam berada dibawah naungan screen yang dilapisi dengan paranet dengan kapasitas untuk menyaring sinar matahari $70 \%$, sehingga tanaman tidak terkena paparan sinar matahari dan tetesan air hujan secara langsung. Iswanto (2010) menyatakan bahwa suhu pada siang hari yang dibutuhkan untuk 
anggrek Cattleya sebesar $21-30^{\circ} \mathrm{C}$ dengan kapasitas cahaya sedang sampai terang.

Serangan dari hama kutu perisai Aspidiella Hartii Cock. (Hemiptera : Diaspididae) menyerang daun pada beberapa tanaman genotipe $\mathrm{CM}$ atau Cattleya Mantini (C. Dowiana $x \quad C$. Bowringiana) pada minggu ke 2 setelah dilakukan perlakuan. Penelitian Balfas (2010) menunjukan bahwa kutu perisai menempel pada permukaan tanaman. Serangan berat akibat hisapan kutu terlihat pada seluruh permukaan tanaman berupa bintik berwarna coklat, yang membuat tanaman terlihat kusam.

\section{Data Kualitatif}

Data kualitatif diamati untuk mengetahui keragaman karakter morfologi daun dan karakter morfologi bunga dari 3 genotipe anggrek Cattleya yang diuji. Karakterisasi morfologi perlu dilakukan terutama untuk keperluan identifikasi fenotipe dan peubahnya terkait dengan ekotipe atau perubahan-perubahan lingkungan (Marzuki et al 2008).

Hasil dari karakterisasi morfologi daun tanaman yang telah dilakukan disajikan pada tabel 1. Berdasarkan data yang didapat mengenai karakter morfologi daun yaitu penampang melintang daun, bentuk ujung daun, susunan, bentuk tepi daun, dan tekstur permukaan daun genotipe anggrek Cattleya tidak ada keragaman.

Tabel 1 Hasil karakterisasi morfologi daun anggrek Cattleya

\begin{tabular}{|c|c|c|c|c|c|c|c|}
\hline \multirow[b]{2}{*}{ Genotipe } & \multicolumn{7}{|c|}{ Karakter Morfologi Daun } \\
\hline & $\begin{array}{c}\text { Penampang } \\
\text { melintang daun }\end{array}$ & Bentuk & Bentuk ujung & Susunan & $\begin{array}{c}\text { Bentuk } \\
\text { tepi }\end{array}$ & $\begin{array}{c}\text { Tekstur } \\
\text { permukaan }\end{array}$ & Simetri \\
\hline $\mathrm{CM}$ & $\begin{array}{l}\text { Bilaterarly } \\
\text { compressed } \\
\text { (zigomorf / tipe } \\
\text { simetri daun) }\end{array}$ & $\begin{array}{l}\text { Oblong/l } \\
\text { onjong }\end{array}$ & $\begin{array}{l}\text { Retuse/ } \\
\text { romping/ } \\
\text { tumpul } \\
\text { bertakik } \\
\text { sedikit }\end{array}$ & $\begin{array}{l}\text { Duplicate/r } \\
\text { angkap }\end{array}$ & $\begin{array}{l}\text { Entirel } \\
\text { mengutuh }\end{array}$ & $\begin{array}{l}\text { Glabrous/ } \\
\text { gundul }\end{array}$ & Simetri \\
\hline $\mathrm{CCY}$ & $\begin{array}{l}\text { Bilaterarly } \\
\text { compressed } \\
\text { (zigomorf / tipe } \\
\text { simetri daun) }\end{array}$ & $\begin{array}{l}\text { Oblong/l } \\
\text { onjong }\end{array}$ & $\begin{array}{l}\text { Retuse/ } \\
\text { romping/ } \\
\text { tumpul } \\
\text { bertakik } \\
\text { sedikit }\end{array}$ & $\begin{array}{l}\text { Duplicate/r } \\
\text { angkap }\end{array}$ & $\begin{array}{l}\text { Entirel } \\
\text { mengutuh }\end{array}$ & $\begin{array}{l}\text { Glabrous/ } \\
\text { gundul }\end{array}$ & $\begin{array}{l}\text { Tidak } \\
\text { simetri }\end{array}$ \\
\hline CWPT & $\begin{array}{l}\text { Bilaterarly } \\
\text { compressed } \\
\text { (zigomorf / tipe } \\
\text { simetri daun) }\end{array}$ & $\begin{array}{l}\text { Elipticl } \\
\text { jorong/ } \\
\text { bujur } \\
\text { telur }\end{array}$ & $\begin{array}{l}\text { Retuse/rompin } \\
\text { g/tumpul } \\
\text { bertakik } \\
\text { sedikit }\end{array}$ & $\begin{array}{l}\text { Duplicate/r } \\
\text { angkap }\end{array}$ & $\begin{array}{l}\text { Entirel } \\
\text { mengutuh }\end{array}$ & $\begin{array}{l}\text { Glabrous/ } \\
\text { gundul }\end{array}$ & Simetri \\
\hline
\end{tabular}

Keterangan : CM : Cattleya mantini, CCY : Cattleya chun yeah, CWPT : Cattleya warneri purple tounge.

Berdasarkan data yang diamati, keragaman terdapat pada bentuk dan simetri daun dari ketiga genotipe yang diamati. Variasi sifat fenotipe disebabkan oleh adanya kerjasama antara genotipe dan keadaan lingkungan (Allard 1960). Hasil karakterisasi morfologi daun anggrek Cattleya yang diuji ditampilkan pada tabel 1 .

Tabel 2 Hasil karakterisasi morfologi bunga anggrek Cattleya

\begin{tabular}{|c|c|c|c|c|c|}
\hline \multirow[b]{2}{*}{ Aksesi } & \multicolumn{5}{|c|}{ Karakter morfologi bunga } \\
\hline & $\begin{array}{c}\text { Posisi } \\
\text { pembungaan }\end{array}$ & Tipe pembungaan & Resupinasi & Perhiasan & Bentuk \\
\hline $\mathrm{CM}$ & Pucuk & Racemose/raceme/tandan & $\begin{array}{l}\text { Resupinat } \\
\text { (terpuntir) }\end{array}$ & $\begin{array}{l}\text { Sepal dorsal, sepal lateral, } \\
\text { petal, dan bibir }\end{array}$ & Bulat \\
\hline $\mathrm{CCY}$ & Pucuk & Racemose/raceme/tandan & $\begin{array}{l}\text { Resupinat } \\
\text { (terpuntir) }\end{array}$ & $\begin{array}{l}\text { Sepal dorsal, sepal lateral, } \\
\text { petal, dan bibir }\end{array}$ & Bulat \\
\hline CWPT & Pucuk & Racemose/raceme/tandan & $\begin{array}{l}\text { Resupinat } \\
\text { (terpuntir) }\end{array}$ & $\begin{array}{l}\text { Sepal dorsal, sepal lateral, } \\
\text { petal, dan bibir }\end{array}$ & Bulat \\
\hline
\end{tabular}

Keterangan : CM : Cattleya mantini, CCY : Cattleya chun yeah, CWPT : Cattleya warneri purple tounge.

Pada karakter morfologi bunga pada 3 genotipe hibrida anggrek Cattleya yang diamati tidak terdapat suatu keragaman baik pada posisi pembungaan, tipe pembungaan, resupinasi, perhiasan, serta bentuk bunga dari anggrek Cattleya yang diamati. Hasil karakterisasi 
morfologi bunga pada anggrek Cattleya yang diuji di sajikan pada tabel 2 .

\section{Data Kuantitatif}

Data kuantitatif karakter morfologi terdiri dari 5 peubah pengamatan yaitu pertambahan jumlah daun, pertambahan panjang daun, pertambahan lebar daun, pertambahan tebal daun, serta muncul anakan baru. Berdasarkan hasil uji statistik pada 3 genotipe anggrek yang diuji terhadap 5 peubah pengamatan didapatkan nilai koefisien keragaman sebesar 8-29\%. Syahid (2009) menyatakan bahwa gambaran tentang seberapa jauh keragaman yang terdapat di dalam suatu percobaan disebut dengan koefisien keragaman. Nilai koefisien keragaman dikatakan sedang apabila minimal $5-10 \%$ pada kondisi homogen atau $10-20 \%$ pada kondisi heterogen. Nilai koefisien keragaman ini maksimal 5\% pada kondisi homogen bernilai kecil dan $10 \%$ pada kondisi heterogen bernilai besar (Hanafiah 1991). Jika koefisien keragaman terlalu besar akan menyebabkan tidak adanya perlakuan yang menonjol secara logis (Syahid 2009).

Tabel 3 Pengaruh Perlakuan Pupuk pada Genotipe CM Cattleya Mantini

\begin{tabular}{|c|c|c|c|c|c|c|}
\hline \multirow{2}{*}{ Perlakuan } & \multicolumn{6}{|c|}{ Minggu Setelah Perlakuan (MSP) } \\
\hline & 2 & 4 & 6 & 8 & 10 & 12 \\
\hline \multicolumn{7}{|c|}{--------------Pertambahan Jumlah Daun (PJD)------------- } \\
\hline $\mathrm{P} 1$ & - & 0.4 & $0.5 \mathrm{ab}$ & $0.6 a b$ & 1.2 & $1.3 \mathrm{a}$ \\
\hline $\mathrm{P} 2$ & $0.2 \mathrm{ab}$ & 0.4 & $0.8 \mathrm{a}$ & $1.1 \mathrm{a}$ & 1.2 & $1.4 \mathrm{a}$ \\
\hline P3 & $0.4 \mathrm{a}$ & 0.6 & $0.7 \mathrm{ab}$ & $0.7 \mathrm{ab}$ & 1.0 & $1.0 \mathrm{ab}$ \\
\hline $\mathrm{P} 4$ & - & - & - & - & 0.2 & $0.2 \mathrm{~b}$ \\
\hline $\operatorname{Pr}>\mathrm{F}$ & $0.09^{\mathrm{tn}}$ & $0.31^{\mathrm{tn}}$ & $0.13^{\text {tn }}$ & $0.03 *$ & $0.06^{\mathrm{tn}}$ & $0.03 *$ \\
\hline $\mathrm{KK}(\%)$ & 25.67 & 10.28 & 11.21 & 10.40 & 10.72 & 10.89 \\
\hline \multicolumn{7}{|c|}{----------Pertambahan Panjang Daun (PPD)----------- } \\
\hline $\mathrm{P} 1$ & 0.80 & 1.11 & 1.21 & 1.31 & 1.52 & 1.60 \\
\hline $\mathrm{P} 2$ & 0.77 & 1.03 & 1.14 & 1.27 & 1.38 & 1.49 \\
\hline P3 & 0.90 & 1.07 & 1.31 & 1.39 & 1.58 & 1.67 \\
\hline P4 & 0.84 & 1.12 & 1.23 & 1.36 & 1.49 & 1.51 \\
\hline $\operatorname{Pr}>\mathrm{F}$ & $0.99^{\text {tn }}$ & $0.99^{\text {tn }}$ & $0.97^{\mathrm{tn}}$ & $0.98^{\mathrm{tn}}$ & $0.95^{\mathrm{tn}}$ & $0.95^{\mathrm{tn}}$ \\
\hline KK (\%) & 29.83 & 27.15 & 24.29 & 23.73 & 23.60 & 23.97 \\
\hline \multicolumn{7}{|c|}{--------------Pertambahan Lebar Daun (PLD)------------- } \\
\hline $\mathrm{P} 1$ & $0.21 \mathrm{ab}$ & $0.28 \mathrm{ab}$ & $0.41 \mathrm{ab}$ & $0.46 \mathrm{ab}$ & 0.48 & 0.49 \\
\hline $\mathrm{P} 2$ & $0.40 \mathrm{a}$ & $0.49 \mathrm{a}$ & $0.60 \mathrm{a}$ & $0.60 \mathrm{a}$ & 0.60 & 0.61 \\
\hline P3 & $0.18 \mathrm{ab}$ & $0.34 \mathrm{ab}$ & $0.37 \mathrm{ab}$ & $0.48 \mathrm{ab}$ & 0.62 & 0.62 \\
\hline $\mathrm{P} 4$ & $0.1 \mathrm{~b}$ & $0.17 \mathrm{~b}$ & $0.22 b$ & $0.26 \mathrm{~b}$ & 0.27 & 0.27 \\
\hline $\operatorname{Pr}>\mathrm{F}$ & $0.13^{\text {th }}$ & $0.07^{\mathrm{tn}}$ & $0.05 *$ & $0.10^{\operatorname{tn}}$ & $0.10^{\mathrm{tn}}$ & $0.10^{\mathrm{tn}}$ \\
\hline $\mathrm{KK}(\%)$ & 16.96 & 15.05 & 14.50 & 15.00 & 16.55 & 16.71 \\
\hline \multicolumn{7}{|c|}{--------------Pertambahan Tebal Daun (PTD)------------- } \\
\hline P1 & 0.08 & 0.24 & 0.27 & 0.27 & 0.28 & 0.28 \\
\hline $\mathrm{P} 2$ & 0.18 & 0.31 & 0.34 & 0.34 & 0.34 & 0.41 \\
\hline P3 & 0.08 & 0.20 & 0.24 & 0.24 & 0.25 & 0.31 \\
\hline $\mathrm{P} 4$ & 0.06 & 0.19 & 0.24 & 0.25 & 0.25 & 0.34 \\
\hline $\operatorname{Pr}>\mathrm{F}$ & $0.45^{\mathrm{tn}}$ & $0.69^{\text {th }}$ & $0.70^{\text {tn }}$ & $0.74^{\text {tn }}$ & $0.78^{\text {tn }}$ & $0.76^{\mathrm{tn}}$ \\
\hline $\mathrm{KK}(\%)$ & 12.41 & 14.12 & 12.94 & 12.78 & 12.77 & 15.10 \\
\hline \multicolumn{7}{|c|}{-------Muncul Anakan Baru (MAB)------- } \\
\hline $\mathrm{P} 1$ & 0.3 & 0.7 & 1.3 & $2.1 \mathrm{a}$ & $2.6 \mathrm{a}$ & $3.2 \mathrm{a}$ \\
\hline $\mathrm{P} 2$ & 0.3 & 0.7 & 1.2 & $1.8 \mathrm{ab}$ & $2.5 \mathrm{a}$ & $3.2 \mathrm{ab}$ \\
\hline P3 & 0.4 & 0.6 & 1.2 & $2.0 \mathrm{ab}$ & $3.1 \mathrm{a}$ & $4.2 \mathrm{a}$ \\
\hline $\mathrm{P} 4$ & 0.1 & 0.2 & 0.4 & $0.6 b$ & $0.8 \mathrm{~b}$ & $1.4 \mathrm{~b}$ \\
\hline $\operatorname{Pr}>\mathrm{F}$ & $0.63^{\text {tn }}$ & $0.21^{\mathrm{tn}}$ & $0.19^{\mathrm{tn}}$ & $0.09^{\mathrm{tn}}$ & $0.03 *$ & $0.05^{*}$ \\
\hline $\mathrm{KK}(\%)$ & 8.35 & 10.72 & 12.50 & 13.32 & 13.50 & 13.99 \\
\hline \multicolumn{7}{|c|}{ 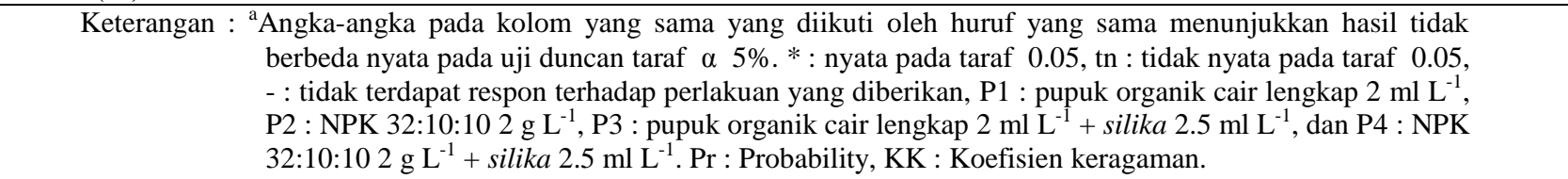 } \\
\hline \multicolumn{4}{|c|}{$\begin{array}{l}\text { Daun yang muncul dihitung menjadi daun } \\
\text { saat daun telah membuka sempurna }\end{array}$} & \multicolumn{3}{|c|}{$\begin{array}{l}\text { meskipun ukurannya masih relatif kecil dan masih } \\
\text { dapat bertambah panjang, lebar dan tebalnya. } \\
\text { Anggrek memiliki keanekaragaman bentuk, }\end{array}$} \\
\hline
\end{tabular}


ukuran maupun ketebalan daun. Tiap daun berbeda tebalnya, ada yang tipis, tebal, rata dan kaku (Darmono 2004). Pengamatan daun anggrek yang diuji dilakukan setiap dua minggu sekali dan dilakukan pada pagi hari.

Tabel 3 menunjukan hasil perlakuan pupuk berpengaruh nyata pada genotipe CM terhadap pertambahan jumlah daun pada minggu ke 8 dan akhir perlakuan yaitu minggu ke 12 . Perlakuan pupuk organik cair lengkap $2 \mathrm{ml} \mathrm{L}^{-1}+$ silika $2.5 \mathrm{ml} \mathrm{L}^{-1}$ memberikan pengaruh paling tinggi pada minggu ke 2. Minggu ke 6 sampai ke 8 perlakuan pupuk anorganik atau NPK 32:10:10 $2 \mathrm{~g} \mathrm{~L}^{-1}$ menunjukan pengaruh yang paling tinggi terhadap pertambahan jumlah daun untuk genotipe ini. Perlakuan pemupukan tidak berpengaruh nyata terhadap pertambahan jumlah daun untuk genotipe CM pada minggu ke 2, 4, 6 dan 10. Genotipe dan lingkungan merupakan faktor yang mempengaruhi jumlah dan ukuran daun (Humphries dan Wheeler 1963 dalam Gardner et al. 1991).

Hasil menunjukan pertambahan panjang dan tebal daun genotipe CM tidak nyata selama perlakuan diberikan. Pada pertambahan lebar daun anggrek genotipe $\mathrm{CM}$, perlakuan pupuk memberikan hasil yang nyata hanya pada minggu ke 6 setelah diberikan perlakuan. Menurut Suharno et al. (2007) bahwa keberadaan unsur nitrogen juga sangat penting terutama kaitannya dengan pertumbuhan tanaman. Unsur $\mathrm{N}$ menyebabkan perkembangan permukaan daun yang lebih cepat, sedangkan unsur $\mathrm{P}, \mathrm{K}, \mathrm{Mg}, \mathrm{Ca}$, dan $S$ juga berperan dalam menunjang pertumbuhan lebar daun (Suwandi dan Chan 1982).

Tabel 4 Pengaruh Perlakuan Pupuk pada Genotipe CCY Cattleya Chun Yeah

\begin{tabular}{|c|c|c|c|c|c|c|}
\hline \multirow{2}{*}{ Perlakuan } & \multicolumn{6}{|c|}{ Minggu Setelah Perlakuan (MSP) } \\
\hline & 2 & 4 & 6 & 8 & 10 & 12 \\
\hline \multicolumn{7}{|c|}{--------------Pertambahan Jumlah Daun (PJD)------------- } \\
\hline $\mathrm{P} 1$ & - & 0.1 & 0.2 & 0.2 & 0.4 & 0.4 \\
\hline $\mathrm{P} 2$ & - & - & 0.1 & 0.1 & 0.2 & 0.2 \\
\hline P3 & - & 0.1 & 0.1 & 0.2 & 0.2 & 0.2 \\
\hline $\mathrm{P} 4$ & - & 0.1 & 0.1 & 0.1 & 0.2 & 0.2 \\
\hline $\operatorname{Pr}>\mathrm{F}$ & - & $0.80^{\text {tn }}$ & $0.88^{\text {tn }}$ & $0.86^{\mathrm{tn}}$ & $0.90^{\operatorname{tn}}$ & $0.90^{\text {tn }}$ \\
\hline $\mathrm{KK}(\%)$ & - & 19.93 & 24.13 & 25.50 & 8.74 & 8.74 \\
\hline \multicolumn{7}{|c|}{  } \\
\hline $\mathrm{P} 1$ & 0.94 & 1.23 & 1.39 & 1.52 & 1.80 & 1.98 \\
\hline $\mathrm{P} 2$ & 0.28 & 0.76 & 0.93 & 1.17 & 1.39 & 1.48 \\
\hline P3 & 1.07 & 1.52 & 1.69 & 1.73 & 1.81 & 1.84 \\
\hline P4 & 0.64 & 0.80 & 1.03 & 1.19 & 1.23 & 1.31 \\
\hline $\operatorname{Pr}>\mathrm{F}$ & $0.41^{\text {tn }}$ & $0.37^{\mathrm{tn}}$ & $0.37^{\mathrm{tn}}$ & $0.57^{\mathrm{tn}}$ & $0.48^{\mathrm{tn}}$ & $0.49^{\text {tn }}$ \\
\hline $\mathrm{KK}(\%)$ & 10.72 & 29.27 & 26.75 & 25.60 & 24.82 & 25.52 \\
\hline \multicolumn{7}{|c|}{-------------Pertambahan Lebar Daun (PLD)------------- } \\
\hline $\mathrm{P} 1$ & 0.19 & 0.21 & 0.29 & 0.30 & 0.33 & 0.36 \\
\hline $\mathrm{P} 2$ & 0.07 & 0.16 & 0.18 & 0.21 & 0.23 & 0.24 \\
\hline P3 & 0.13 & 0.21 & 0.27 & 0.32 & 0.37 & 0.41 \\
\hline $\mathrm{P} 4$ & 0.07 & 0.13 & 0.16 & 0.21 & 0.26 & 0.26 \\
\hline $\operatorname{Pr}>\mathrm{F}$ & $0.15^{\text {tn }}$ & $0.74^{\text {tn }}$ & $0.34^{\text {tn }}$ & $0.47^{\text {tn }}$ & $0.48^{\text {tn }}$ & $0.35^{\text {tn }}$ \\
\hline KK (\%) & 10.01 & 13.67 & 12.93 & 12.76 & 13.14 & 13.80 \\
\hline \multicolumn{7}{|c|}{---------Pertambahan Tebal Daun (PTD)---------- } \\
\hline P1 & 0.02 & 0.19 & 0.24 & 0.24 & 0.24 & 0.27 \\
\hline $\mathrm{P} 2$ & 0.08 & 0.26 & 0.27 & 0.28 & 0.30 & 0.51 \\
\hline P3 & 0.08 & 0.18 & 0.19 & 0.20 & 0.21 & 0.29 \\
\hline $\mathrm{P} 4$ & 0.04 & 0.15 & 0.16 & 0.16 & 0.16 & 0.24 \\
\hline $\operatorname{Pr}>\mathrm{F}$ & $0.45^{\mathrm{tn}}$ & $0.85^{\mathrm{tn}}$ & $0.77^{\mathrm{tn}}$ & $0.76^{\mathrm{tn}}$ & $0.74^{\text {tn }}$ & $0.66^{\mathrm{tn}}$ \\
\hline $\mathrm{KK}(\%)$ & 7.51 & 15.40 & 14.62 & 14.83 & 15.16 & 22.54 \\
\hline \multicolumn{7}{|c|}{---------Muncul Anakan Baru (MAB)--------- } \\
\hline P1 & 0.3 & 0.7 & 1.1 & 1.1 & 1.1 & 1.2 \\
\hline $\mathrm{P} 2$ & 0.1 & 0.3 & 0.4 & 1.2 & 1.7 & 2.5 \\
\hline P3 & 0.2 & 0.5 & 0.8 & 1.1 & 1.3 & 1.8 \\
\hline $\mathrm{P} 4$ & 0.2 & 0.3 & 0.4 & 0.6 & 1.0 & 1.4 \\
\hline $\operatorname{Pr}>\mathrm{F}$ & $0.88^{\text {tn }}$ & $0.77^{\mathrm{tn}}$ & $0.73^{\text {tn }}$ & $0.84^{\mathrm{tn}}$ & $0.69^{\operatorname{tn}}$ & $0.34^{\text {tn }}$ \\
\hline KK (\%) & 8.23 & 9.73 & 13.99 & 15.11 & 15.79 & 14.89 \\
\hline
\end{tabular}

Keterangan : angka-angka pada kolom yang sama yang diikuti oleh huruf yang sama menunjukkan hasil tidak berbeda nyata pada uji duncan taraf $\alpha 5 \%$. tn : tidak nyata pada taraf 0.05 , - : tidak terdapat respon terhadap perlakuan yang diberikan, P1 : pupuk organik cair lengkap $2 \mathrm{ml} \mathrm{L}^{-1}$, P2: NPK 32:10:10 $2 \mathrm{~g} \mathrm{~L}^{-1}, \mathrm{P} 3$ : pupuk organik cair lengkap $2 \mathrm{ml} \mathrm{L}^{-1}+$ silika 2.5 $\mathrm{ml} \mathrm{L}^{-1}$, dan P4 : NPK 32:10:102 $\mathrm{g} \mathrm{L}^{-1}+$ silika $2.5 \mathrm{ml} \mathrm{L}^{-1}$. Pr : Probability, KK : Koefisien keragaman. 
Perlakuan pupuk tidak memberikan pengaruh nyata terhadap munculnya anakan baru pada anggrek genotipe CM minggu ke 2 sampai ke 8. Perlakuan pupuk memberikan pengaruh nyata pada minggu ke 10 sampai ke 12 genotipe CM sesuai Tabel 3. Muncul anakan baru rata-rata sebanyak 3 anakan pada minggu ke 10 dan 4 anakan baru pada minggu ke 12 pemberian pupuk organik cair lengkap yang ditambahkan dengan silika ( $\mathrm{Si})$, hal ini menunjukan hasil yang paling tinggi dibanding pemberian pupuk yang lain pada genotipe CM.

Tabel 4 menunjukan bahwa perlakuan pupuk memberikan hasil yang tidak nyata pada seluruh peubah pengamatan selama perlakuan pada genotipe. Hasil menunjukan pemberian pupuk organik cair lengkap mendorong pertambahan panjang daun hampir $2 \mathrm{~cm}$ yaitu rata-rata sebesar $1.98 \mathrm{~cm}$ pada akhir perlakuan, hal ini menunjukan hasil paling tinggi dibanding pemberian pupuk yang lain terhadap genotipe CCY. Pemberian pupuk NPK 32:10:10 $2 \mathrm{~g} \mathrm{~L}^{-1}$ pada akhir perlakuan dapat mendorong munculnya anakan baru paling banyak dibanding pemberian pupuk lain yaitu sebanyak 2 anakan pada genotipe CCY.

Tabel 5 Pengaruh Perlakuan Pupuk pada Genotipe CWPT Cattleya Warneri Purple Tounge

\begin{tabular}{|c|c|c|c|c|c|c|}
\hline \multirow{2}{*}{ Perlakuan } & \multicolumn{6}{|c|}{ Minggu Setelah Perlakuan (MSP) } \\
\hline & 2 & 4 & 6 & 8 & 10 & 12 \\
\hline \multicolumn{7}{|c|}{------------Pertambahan Jumlah Daun (PJD)------------- } \\
\hline $\mathrm{P} 1$ & - & - & - & - & - & - \\
\hline $\mathrm{P} 2$ & 0.3 & 0.3 & 0.3 & 0.3 & 0.3 & 0.3 \\
\hline P3 & - & - & - & - & 0.1 & 0.1 \\
\hline P4 & - & - & - & - & - & - \\
\hline $\operatorname{Pr}>\mathrm{F}$ & $0.01 * *$ & $0.01 * *$ & $0.01 * *$ & $0.01 * *$ & $0.08^{\operatorname{tn}}$ & $0.08^{\mathrm{tn}}$ \\
\hline $\mathrm{KK}(\%)$ & 17.26 & 17.26 & 17.24 & 17.24 & 20.34 & 20.36 \\
\hline \multicolumn{7}{|c|}{--------------Pertambahan Panjang Daun (PPD)------------- } \\
\hline $\mathrm{P} 1$ & $0.31 \mathrm{~b}$ & 0.97 & 1.19 & 1.28 & 1.51 & 1.63 \\
\hline $\mathrm{P} 2$ & $1.01 \mathrm{a}$ & 1.40 & 1.48 & 1.60 & 1.79 & 1.92 \\
\hline P3 & $0.61 \mathrm{ab}$ & 0.94 & 1.12 & 1.21 & 1.23 & 1.27 \\
\hline $\mathrm{P} 4$ & $0.52 \mathrm{ab}$ & 0.78 & 1.00 & 1.09 & 1.13 & 1.17 \\
\hline $\operatorname{Pr}>\mathrm{F}$ & $0.03 *$ & $0.20^{\mathrm{tn}}$ & $0.46^{\mathrm{tn}}$ & $0.46^{\mathrm{tn}}$ & $0.27^{\mathrm{tn}}$ & $0.23^{\mathrm{tn}}$ \\
\hline $\mathrm{KK}(\%)$ & 22.09 & 20.77 & 19.37 & 19.86 & 19.56 & 20.81 \\
\hline \multicolumn{7}{|c|}{---------------Pertambahan Lebar Daun (PLD)-------------- } \\
\hline $\mathrm{P} 1$ & $0.51 \mathrm{a}$ & $0.53 \mathrm{a}$ & $0.57 \mathrm{a}$ & $0.59 \mathrm{a}$ & $0.63 \mathrm{a}$ & $0.63 \mathrm{a}$ \\
\hline $\mathrm{P} 2$ & $0.20 \mathrm{~b}$ & $0.24 \mathrm{ab}$ & $0.33 \mathrm{ab}$ & $0.33 \mathrm{ab}$ & $0.37 \mathrm{ab}$ & $0.37 \mathrm{ab}$ \\
\hline P3 & $0.28 \mathrm{ab}$ & $0.38 \mathrm{a}$ & $0.43 \mathrm{ab}$ & $0.46 \mathrm{ab}$ & $0.47 \mathrm{ab}$ & $0.47 \mathrm{ab}$ \\
\hline $\mathrm{P} 4$ & $0.07 b$ & $0.08 b$ & $0.18 b$ & $0.20 \mathrm{~b}$ & $0.22 b$ & $0.24 b$ \\
\hline $\operatorname{Pr}>\mathrm{F}$ & $0.02 *$ & $0.01 * *$ & $0.08^{\text {tn }}$ & $0.07^{\operatorname{tn}}$ & $0.06^{\mathrm{tn}}$ & $0.09^{\mathrm{tn}}$ \\
\hline KK (\%) & 17.63 & 17.17 & 16.91 & 16.39 & 16.19 & 16.40 \\
\hline \multicolumn{7}{|c|}{-----------Pertambahan Tebal Daun (PTD)----------- } \\
\hline $\mathrm{P} 1$ & 0.01 & 0.10 & 0.15 & 0.16 & 0.16 & 0.22 \\
\hline $\mathrm{P} 2$ & 0.09 & 0.16 & 0.23 & 0.23 & 0.24 & 0.27 \\
\hline P3 & 0.03 & 0.11 & 0.21 & 0.21 & 0.23 & 0.23 \\
\hline P4 & 0.05 & 0.12 & 0.15 & 0.15 & 0.15 & 0.15 \\
\hline $\operatorname{Pr}>\mathrm{F}$ & $0.37^{\mathrm{tn}}$ & $0.84^{\text {tn }}$ & $0.59^{\operatorname{tn}}$ & $0.61^{\text {tn }}$ & $0.54^{\mathrm{tn}}$ & $0.55^{\mathrm{tn}}$ \\
\hline KK $(\%)$ & 8.31 & 10.68 & 11.44 & 11.42 & 11.22 & 12.41 \\
\hline \multicolumn{7}{|c|}{----------Muncul Anakan Baru (MAB)--------- } \\
\hline $\mathrm{P} 1$ & - & - & - & - & - & 0.1 \\
\hline $\mathrm{P} 2$ & - & - & 0.1 & 0.2 & 0.5 & 0.8 \\
\hline P3 & - & 0.1 & 0.2 & 0.4 & 0.6 & 0.7 \\
\hline P4 & - & - & - & - & - & 0.1 \\
\hline $\operatorname{Pr}>\mathrm{F}$ & - & $0.40^{\operatorname{tn}}$ & $0.55^{\text {tn }}$ & $0.25^{\mathrm{tn}}$ & $0.16^{\mathrm{tn}}$ & $0.30^{\mathrm{tn}}$ \\
\hline $\mathrm{KK}(\%)$ & - & 11.96 & 22.70 & 29.67 & 10.87 & 12.03 \\
\hline
\end{tabular}

Keterangan : ${ }^{a}$ Angka-angka pada kolom yang sama yang diikuti oleh huruf yang sama menunjukkan hasil tidak berbeda nyata pada uji duncan taraf $\alpha 5 \%$. ${ }^{* *}$ : sangat nyata pada taraf $0.01 *$ : nyata pada taraf 0.05 , tn : tidak nyata pada taraf 0.05 , - : tidak terdapat respon terhadap perlakuan yang diberikan, $\mathrm{P} 1$ : pupuk organik cair lengkap $2 \mathrm{ml}$ $\mathrm{L}^{-1}$, P2 : NPK 32:10:10 $2 \mathrm{~g} \mathrm{~L}^{-1}, \mathrm{P} 3$ : pupuk organik cair lengkap $2 \mathrm{ml} \mathrm{L}^{-1}+$ silika $2.5 \mathrm{ml} \mathrm{L}^{-1}$, dan P4: NPK 32:10:10 $2 \mathrm{~g} \mathrm{~L}^{-1}+$ silika $2.5 \mathrm{ml} \mathrm{L}^{-1}$. Pr : Probability, KK : Koefisien keragaman.

Berdasarkan Tabel 5 perlakuan pupuk organik cair lengkap $2 \mathrm{ml} \mathrm{L}^{-1}$ dan NPK 32:10:10 2 $\mathrm{g} \mathrm{L}^{-1}+$ silika $2.5 \mathrm{ml} \mathrm{L}^{-1}$ tidak memberikan respon terhadap pertambahan jumlah daun selama 
perlakuan diberikan pada genotipe CWPT. Perlakuan pupuk memberikan respon pertambahan jumlah daun hanya pupuk NPK 32:10:10 $2 \mathrm{~g} \mathrm{~L}^{-1}$ sehingga perlakuan pupuk berpengaruh nyata terhadap pertambahan jumlah daun dari minggu ke 2 sampai ke 8 . Hasil menunjukan tidak nyata pada minggu ke 10 sampai ke 12 karena ada 2 perlakuan pupuk yang memberikan hasil yang sama yaitu pupuk NPK 32:10:10 $2 \mathrm{~g} \mathrm{~L}^{-1}$ dan pupuk organik cair lengkap 2 $\mathrm{ml} \mathrm{L}{ }^{-1}+$ silika $2.5 \mathrm{ml} \mathrm{L}^{-1}$ terhadap pertambahan jumlah daun pada genotipe CWPT.

Pemberian pupuk menunjukan hasil yang nyata pada minggu ke 2 pertambahan panjang daun. Perlakuan pupuk NPK 32:10:10 $2 \mathrm{~g} \mathrm{~L}^{-1}$ memberikan hasil yang paling tinggi rata-rata sebesar $1.01 \mathrm{~cm}$ pada minggu ke 2 dibanding perlakuan pupuk yang lain. Hasil statistik Tabel 5 menunjukan bahwa perlakuan pupuk memberikan hasil tidak nyata terhadap pertambahan panjang daun pada minggu ke 4 sampai ke 12 . Genotipe CWPT menunjukan hasil pertambahan panjang daun paling tinggi selama pengamatan pada perlakuan pupuk NPK 32:10:10 $2 \mathrm{~g} \mathrm{~L}^{-1}$.

Berdasarkan Tabel 5 perlakuan pupuk memberikan hasil yang nyata dan sangat nyata terhadap pertambahan lebar daun pada minggu ke 2 dan ke 4. Perlakuan pupuk organik cair lengkap $2 \mathrm{ml} \mathrm{L}^{-1}$ memberikan hasil yang paling tinggi terhadap pertambahan lebar daun pada genotipe CWPT selama perlakuan diberikan. Hasil analisis menunjukan bahwa perlakuan pupuk berpengaruh tidak nyata terhadap pertambahan lebar daun pada minggu ke 6 sampai ke 12 genotipe CWPT. Tabel 5 menunjukan bahwa perlakuan pupuk tidak berpengaruh nyata terhadap pertambahan tebal daun dan muncul anakan baru selama perlakuan diberikan.

Hasil uji statistik menunjukan bahwa perlakuan pupuk yang paling rendah memberikan hasil terhadap semua peubah pengamatan dan semua genotipe selama perlakuan diberikan adalah pupuk NPK 32:10:10 $2 \mathrm{~g} \mathrm{~L}^{-1}+$ silika 2.5 $\mathrm{ml} \mathrm{L}^{-1}$ dibanding pupuk yang lain. Pecampuran dua jenis senyawa yaitu NPK 32:10:10 $2 \mathrm{~g} \mathrm{~L}^{-1}$ dan silika $2.5 \mathrm{ml} \mathrm{L}^{-1}$ menimbulkan suatu gumpalan yang tidak dapat larut didalam air. Percampuran senyawa dilakukan dengan memasukan air terlebih dahulu setelah diketahui terjadi penggumpalan antara dua senyawa tersebut.

\section{KESIMPULAN}

Karakterisasi morfologi 3 genotipe hibrida anggrek Cattleya menunjukan bahwa tidak terdapat keragaman pada morfologi daun anggrek pada penampang melintang daun, bentuk ujung, susunan, bentuk tepi dan tekstur permukaan daun.
Keragaman pada daun anggrek Cattleya yang diamati terdapat pada simetri daun. Karakterisasi bunga anggrek Cattleya yang diamati tidak terdapat keragaman pada posisi pembungaan, tipe pembungaan, resupinasi, perhiasan, serta bentuk bunga.

Perlakuan pemupukan yang diberikan selama percobaan yang memberikan hasil paling baik terhadap 5 peubah pengamatan adalah pupuk organik cair lengkap $2 \mathrm{ml} \mathrm{L}^{-1}+$ silika $2.5 \mathrm{ml} \mathrm{L}^{-1}$.

\section{DAFTAR PUSTAKA}

[Balithi] Balai Penelitian Tanaman Hias. 2007. Panduan Karakterisasi Tanaman Hias Anggrek. Jakarta (ID): BALITHI.

[BPS] Badan Pusat Statistik. 2014. Publikasi laporan tanaman hias 2014 (produksi anggrek) [internet]. [diunduh 2014 jan 12]. Tersedia pada: http://www.bps.go.id/

[BPS] Badan Pusat Statistik. 2014. Publikasi laporan tanaman hias 2014 (ekspor anggrek) [internet]. [diunduh 2014 jan 12]. Tersedia pada: http://www.bps.go.id/

Allard, R.W. 1960. Pemuliaan Tanaman. Bandung (ID). Rineka Cipta.

Darmono, D.W. 2004. Bertanam Anggrek. Depok (ID): Penebar Swadaya.

Epstein E. 1999. Silicon Annu. Rev. Plant. Physiol. Plant Mol. Biol. 50: 641-664.

Gardner, F.P., Pearce R.B., Mitchell R.L. 1991. Fisiologi Tanaman Budidaya. Susilo $\mathrm{H}$, penerjemah. Jakarta (ID) : UI Press.

Hanafiah, K.A. 1991. Rancangan Percobaan : Teori dan Aplikasi Cetakan ke-5. Jakarta Utara (ID): Raja Grafindo Persada.

Hew, C.S., Young JWH. 1997. The Physiology of Tropical Orchids in Relation to the Industry. Singapore: World Scientific.

Iswanto, H. 2010. Petunjuk Praktis Merawat Anggrek. Jakarta (ID). Agromedia Pustaka.

\section{Anggrek Phalaenopsis.} Jakarta (ID). Agromedia Pustaka.

Ma, J.F., Takahashi E. 2002. Soil, Fertilizer and Plant Silicon Research in Japan. Elsevier Science B. V. Amsterdam. 
Marzuki, I., Uluputty M.R., Aziz S.A., Surahman M. 2008. Karakterisasi morfoekotipe dan proksimat pada banda (Myristica fragans Houtt.). Bul Agron. 36(2): 145-151.

Mattjik, N.A. 2010. Budi Daya Bunga Potong dan Tanaman Hias. Purwito A, editor. Bogor (ID): IPB Press.

Monger, H.C., Kelly E.F. 2002. Silica minerals, Chap. 20, in Dixon,J. B., Schulze, D. G.: Soil Mineralogy with environmental applications.Book Series SSSA No.7, Madison, WI, pp. 611-636.

[PIOC] Pupuk Ion Organik Cair - Ciremai. 2014. Sumber Unsur Hara Silika (Si) untuk Pertanian (Ilmu Pertanian) [Internet]. [diunduh 2015 Okt 26]. Tersedia pada http://piocCiremai.page4.me/

Puspitasari, D.T. 2006. Pengaruh perlakuan pemupukan terhadap pertumbuhan vegetatif dan generatif tanaman anggrek Dendrobium sp. Var Thouchai Viroj [Skripsi]. Bogor (ID): Institut Pertanian Bogor.

Roidah, I.S. 2013. Manfaat Penggunaan Pupuk Organik untuk Kesuburan Tanah. J.Univ. Tunlungagung BONOROWO. 1(1) : 39-40.

Sander, D. 1979. Orchids and Their Cultivation. 9th. Dorset: Blandford Press.
Santi, T.K. 2005. Pengaruh Dosis Pupuk Mamigro dan Kerapatan Populasi terhadap Pertumbuhan Bibit Anggrek Cattleya. J. Ilmiah Progresive. 2(5) : 2 .

Sitompul, S.M., Bambang G. 1995. Analisis pertumbuhan tanaman. Gadjah Mada University Press. Yogyakarta.

Soepardi, G. 1983. Sifat dan Ciri Tanah. Bogor (ID): IPB Press.

Suharno, Mawardi I, Setiabudi, Lunga N., S. Tjitrosemito. 2007. Efisiensi Penggunaan Nitrogen pada Tipe Vegetasi yang Berbeda di Stasiun Penelitian Cikaniki, Taman Nasional Gunung Halimun Salak, Jawa Barat. J. Biodiversitas (8): 287-294.

Suwandi, Chan F. 1982. Pemupukan pada Tanaman Kelapa Sawit yang Telah Menghasilkan dalam Budidaya Kelapa Sawit (Elaeis guineensis Jacq.) oleh Lubis AU, Jamin A, Wahyuni S dan Harahap IR. Pusat Penelitian Marihat Pematang Siantar. Medan. Hal $19-21$.

Syahid, A. 2009. Koefisien Keragaman [Internet]. [diunduh 2015 Nov. 01]. Tersedia pada: download/12897928/KoefisienKeragaman KK.pdf.html.

Tisdale, S.L., W.L Nelson, J.D Beaton. 1995. Soil Fertily and Fertilizer $4^{\text {th }}$ Ed. Co. New York : MacMillan Publ. 